\title{
Route of vaccine administration: effects on the specific humoral response in rainbow trout Oncorhynchus mykiss
}

\author{
Roger C. Palm Jr ${ }^{1, *}$, Marsha L. Landolt ${ }^{2}$, Robert A. Busch ${ }^{3}$ \\ ${ }^{1}$ Alpharma NW Inc., 1720 130th Avenue NE, Bellevue, Washington 98005, USA \\ ${ }^{2}$ The Graduate School, University of Washington, Seattle, Washington 98195, USA \\ ${ }^{3}$ Landolt Busch \& Associates, 231114 th Avenue East, Seattle, Washington 98112, USA
}

\begin{abstract}
The specific humoral response of teleost fish to extracellular bacteria was examined using a rainbow trout - Vibrio anguillarum model. Treatment groups were immunized by oral, immersion, and injection routes. All 3 delivery methods conferred full protection in controlled laboratory challenges $(\mathrm{p}<0.01)$. Prior to boosting, serum antibody titers did not correlate with protection in the orally and immersion-vaccinated groups, but, contrary to previous studies, titers measured 10 and $17 \mathrm{~d}$ after boosting correlated positively with protection in all 3 vaccinated groups. The route of administration strongly affected the magnitude of the antibody response as measured by enzyme-linked immunosorbent assay (ELISA) and Western blots; however, the antigenic epitopes recognized were not substantially altered by delivery method as evidenced in 1 mmunoblot patterns. Given that the primary and booster vaccination protocols were identical, the data suggest that all 3 vaccinated groups may have had a specific humoral response following initial immunzation but that specific serum antibody levels before boosting were too low to be detected by ELISA nn fish vaccinated by oral and immersion routes. An anamnestic response was evident in all 3 groups. The data support the possibility that teleosts, like higher vertebrates, have a protective immune response to extracellular bacteria that is predominantly humoral. Route of delivery may primarily affect the efficiency with which the immunogenic constituents of the vaccine are presented to the relevant recognition and effector components of the immune system.
\end{abstract}

KEY WORDS: Vaccine Route of delivery - Vibrio anguillarum Humoral immune response - Memory

\section{INTRODUCTION}

Environmental concerns, regulatory constraints, costs, and pathogen resistance have greatly diminished the appeal of antibiotics and other chemotherapeutants in aquaculture. For these reasons, as well as the early successes of immunization against vibriosis and enteric redmouth disease (Busch 1978, Horne et al. 1984), vaccine development is increasingly viewed as a critical area of aquaculture research. New vaccines are needed to counter an expanding array of pathogens, and improvements must be made in delivery methods.

The route by which a vaccine is administered (i.e. parenteral, immersion, oral) appears to exert different effects on immunological parameters. Understanding

•E-mail: fishdoc@aa.net the basis for these differences may not only improve vaccine efficacy, but may also provide valuable insight into the nature of the teleost immune system. To gain such an understanding, in vitro and in vivo methods need to be combined in carefully controlled model systems so that immunological responses evoked by various delivery routes can be correlated with clinical endpoints and measures of protection (e.g. survival following controlled laboratory challenge trials). In the present study, in vitro and in vivo methods were combined and used as tools to evaluate primary and secondary humoral responses to oral, immersion, and injection vaccination. A rainbow trout-Vibrio anguillarum model was utilized in order to take advantage of the extensive literature base that exists for this model, as well as to avoid difficulties that might arise with fastidious species or unusual immune responses. 
Teleost fish are known to be protected by an intricate and well integrated immune system that is functionally comparable to that of higher vertebrates (Gudkovs 1988). It is well established that humoral immunity in higher vertebrates is the principal protective specific immune response against extracellular bacteria (Abbas et al. 1991). For these reasons, enzyme-linked immunosorbent assay (ELISA) and Western blotting techniques were used for the in vitro portion of the study to measure specific humoral responses. The in vivo portions of the experiments consisted of laboratory bath challenges with the homologous pathogen and were designed to produce mortality rates that approximated those observed during typical epizootics.

In addition to establishing a potentially useful and robust experimental model for future vaccine and immunological research, the purpose of this study was to address 4 key questions. First, can levels of circulating specific antibody be positively correlated with protection in fish immunized by injection, immersion, and oral routes? Second, does route of vaccine administration affect the kinetics of the immune response, both before and after boosting? Third, can an anamnestic response be demonstrated utilizing only immersion or oral vaccination? Fourth, does the pattern of antigen recognition, as shown by Western blotting, fundamentally change depending upon the route of vaccine delivery?

\section{METHODS}

Experimental fish. Rainbow trout Oncorhynchus mykiss of the McLeary Steelhead strain (Troutlodge, Sumner, WA, USA) were obtained as eyed eggs and were grown to $10 \mathrm{~g}$ mean weight under specific pathogen-free (SPF) culture conditions. Treatment groups of 200 fish were randomly assigned to $65 \mathrm{l}$ rectangular tanks receiving $2.5 \mathrm{l} \mathrm{min}^{-1}$ of 14 to $16^{\circ} \mathrm{C}$ dechlorinated city water. Except during periods of oral immunization or fasting, fish were fed daily with a commercial trout diet (Silver Cup) at the rate of $4 \%$ body weight $\mathrm{d}^{-1}$

Bacteria. Vibrio anguillarum 775 (serotype 1; obtained from Alpharma NW Inc., Bellevue, WA) was used throughout this study. This strain was chosen due to its minimal antigenic variability (Chart \& Trust 1984) and the associated literature base. Strain 775 was isolated and described from coho (Oncorhynchus kisutch) and sockeye (O. nerka) salmon in Puget Sound, WA (Harrell et al. 1976). All bacterial cultures used for vaccine preparation, antigen preparation, and challenges were grown in 100 to $500 \mathrm{ml}$ batches in tryptic soy broth (Difco Laboratories, Detroit, MI, USA) at $20^{\circ} \mathrm{C}$ for approximately $24 \mathrm{~h}$ on a shaker platform at $200 \mathrm{rpm}$. Baffled flasks (Bellco, Inc., Vineland, NJ, USA) were inoculated with one or two $2 \mathrm{ml}$ seed stock aliquots that had been stored at $-80^{\circ} \mathrm{C}$ final concentrations were approximately $10^{9}$ colony forming units (CFU) $\mathrm{ml}^{-1}$. Standard quality control measures included purity checks, duplicate plate counts at $10^{-7}$ and $10^{-8}$ dilutions, and, in the case of vaccines, sterility checks.

Immunization. The same whole cell, formalin-killed $\left(0.3 \%\right.$ added to culture before storage at $\left.4^{\circ} \mathrm{C}\right)$ bacterin with broth was utilized for all immunizations. Each route of vaccine administration was standardized on the basis of wet pack cell mass. Primary and booster immunizations were carried out using the following identical protocols. Injection-vaccinated fish were first anaesthetized with a $10 \%$ ethyl $p$-aminobenzoate (benzocaine, Sigma, St. Louis, MO, USA) solution (10 g in $1.00 \mathrm{ml}$ ethanol) diluted 1:2000 in water, and then given $0.2 \mathrm{ml}$ ( $4 \mathrm{mg}$ wet pack cell mass) intraperitoneally via an injection gun. Immersion-vaccinated fish were dipped for $40 \mathrm{~s}$ in a 1:4 dilution of the bacterin ( $4 \mathrm{mg}$ wet pack cell mass $\mathrm{ml}^{-1}$ ). The oral vaccine was incorporated into Oregon Test Diet (Sinnhuber et al. 1977) at the rate of $6 \mathrm{mg}$ wet pack cell mass $\mathrm{g}^{-1}$ diet. This was fed at $4.5 \%$ body weight $\mathrm{d}^{-1}$ for $5 \mathrm{~d}$, with $2 \mathrm{~d}$ of fasting before and after administration. For $5 \mathrm{~d}$ during the week preceding immunization, fish were acclimated to the diet without bacterin. All other treatment groups were also given the Oregon Test Diet during the weeks of acclimation and vaccination.

Bleeding and preparation of serum standards. Fish were bled via caudal vein puncture. Blood was immediately diluted $1: 4$ in $0.15 \mathrm{M} \mathrm{NaCl}$ in $1.5 \mathrm{ml}$ polypropylene microcentrifuge tubes and allowed to coagulate and settle overnight at $4{ }^{\circ} \mathrm{C}$. The next day, blood samples were centrifuged for $20 \mathrm{~min}$ at $2000 \times \mathrm{g}$ and serum was stored at $-80^{\circ} \mathrm{C}$. Thus titers are based upon dilutions of whole blood rather than the serum fraction; this procedure improves serum antibody recovery (Palm 1996). For the ELISA and Western blot analyses, positive and negative serum standards were used as controls for day-to-day variability. The positive standard was a high titer, anti-Vibrio anguillarum serum pooled from 90 injection-vaccinated SPF rainbow trout; the negative standard was a pooled serum drawn from 90 unvaccinated SPF rainbow trout.

Challenge protocol. To determine the optimal challenge concentration, an $\mathrm{LD}_{50}$ bath challenge was conducted on 3 groups of control fish at 3 dilutions of a $10^{9} \mathrm{CFU} \mathrm{m} \mathrm{m}^{-1}$ culture $(1: 1000,1: 100,1: 10)$. Accurate challenge doses were calculated from plate counts of serial dilutions of each challenge culture. Five treatment groups were included in the experimental challenges: negative control (not vaccinated, not challenged), positive control (not vaccinated, challenged), 
oral vaccinates, immersion vaccinates, and injection vaccinates. The final static bath challenges lasted 60 min and utilized duplicate 20 -fish groups for each treatment. Challenges were conducted at $15^{\circ} \mathrm{C}$ with aeration; water volumes were adjusted to maintain a density of $100 \mathrm{~g}_{\text {fish } \mathrm{l}^{-1}}$ water. Each replicate group was then randomly assigned and placed in a 18.91 aerated flow-through tank $\left(37.81 \mathrm{~h}^{-1}\right)$ and monitored for $14 \mathrm{~d}$. Water temperature was maintained at $15^{\circ} \mathrm{C}$ and fish were not fed. Dead fish were removed daily and cause of death for each fish was confirmed by reisolation of bacteria from the kidney.

Antigen preparation. For ELISA and Western blot assays, Vibrio anguillarum 775 was grown overnight as previously described and centrifuged at $12000 \times \mathrm{g}$ for $15 \mathrm{~min}$. Cells were resuspended in phosphatebuffered saline (PBS), pH 7.4, and sonicated 3 times for $30 \mathrm{~s}$ with the $13.5 \mathrm{~mm}$ probe for the Vibra-Cell ${ }^{\text {TM }}$ high intensity ultrasonic processor (Sonics \& Materials, Inc., Danbury, CT, USA). Sonicated material was centrifuged at $3000 \times \mathrm{g}$ for $10 \mathrm{~min}$ to remove large cellular debris. The supernatant was drawn off, divided into $1 \mathrm{ml}$ aliquots, and stored at $-80^{\circ} \mathrm{C}$.

ELISA. Antibody titers were determined by ELISA (Engvall \& Perlmann 1972) using the titration method (Tijssen 1985). Immulon I microtiter plates (Dynatech Laboratories, Chantilly, VA, USA) were coated with the Vibrio anguillarum antigen preparation in carbonate buffer ( $\mathrm{pH} 9.6$ ) overnight at $4^{\circ} \mathrm{C}$ at $10 \mu \mathrm{g}$ protein well $^{-1}$ as determined by the Bradford Method (Hammond \& Kruger 1988). After removal of excess antigen, plates were blocked with $200 \mu$ l well-1 of goat diluting buffer (5 ml heat-inactivated goat serum, $95 \mathrm{ml}$ PBS, $50 \mu \mathrm{l}$ Tween 20 ) at $22^{\circ} \mathrm{C}$ for $15 \mathrm{~min}$. Plate wells were washed 3 times $(5.5 \% \mathrm{NaCl}, 0.1 \%$ Tween 20$)$, then incubated at $22^{\circ} \mathrm{C}$ for 60 min with 2 -fold serial dilutions of fish sera in PBS $(1: 10$ to $1: 1280)$. Subsequently, the wells were washed 3 times, and incubated at $37^{\circ} \mathrm{C}$ for 15 min with a 1:320 dilution of the Warr 1-14 (DeLuca et al. 1983) mouse anti-trout monoclonal antibody tissue culture supernatant. Following 3 more washings, the plates were incubated at $37^{\circ} \mathrm{C}$ for $15 \mathrm{~min}$ with a 1:1000 dilution of a goat anti-mouse antibody conjugated to horseradish peroxidase (Kirkegaard and Perry, Gaithersburg, MD, USA). Finally, the 3, 3', 5, 5'tetramethylbenzidine substrate (Kirkegaard and Perry) was added, followed by an equal volume of TMB Stop Solution (Kirkegaard and Perry) 4 min later. Optical density (O.D.) of each well was determined with a microplate reader (Molecular Devices, Menlo Park, CA, USA) at $450 \mathrm{~nm}$.

SDS-PAGE, Western blot, and scanning densitometry. Vibrio anguillarum 775 antigen (4.5 $\mathrm{mg}$ protein $\mathrm{ml}^{-1}$ ) was diluted $1: 1$ in a modified Laemmli buffer (Laemmli 1970 ) containing $1 \mathrm{ml} 0.5 \mathrm{M}$ Tris- $\mathrm{HCl}(\mathrm{pH} 6.8$ ), $0.8 \mathrm{ml}$ glycerol, $1.6 \mathrm{ml} \mathrm{10 \%} \mathrm{sodium} \mathrm{dodecyl} \mathrm{sulphate} \mathrm{(SDS),}$ $0.4 \mathrm{ml} 2$-b-mercaptoethanol, $0.8 \mathrm{ml} 0.05 \%$ bromophenol blue, and $4 \mathrm{ml}$ Type 1 (National Committee for Clinical Laboratory Standards) reagent grade water (ZyzaTech, Seattle, WA). The sample buffer was heated at $100^{\circ} \mathrm{C}$ for $5 \mathrm{~min}$ and then, along with prestained low range molecular weight standards (BioRad, Hercules, CA), was separated (135 $\mu \mathrm{g}$ protein $\mathrm{gel}^{-1}$ ) by sodium dodecyl sulfate-polyacrylamide gel electrophoresis (SDS-PAGE) using a $4 \%$ stacking gel and a $12 \%$ separating gel in a Mini Protean II apparatus (BioRad) at $150 \mathrm{~V}$ for $55 \mathrm{~min}$ at $22^{\circ} \mathrm{C}$. Gels were blotted overnight $(30 \mathrm{~V})$ onto nitrocellulose $(0.45 \mu \mathrm{m}$ pore size) in transfer buffer (25 mM Tris, $192 \mathrm{mM}$ glycine, $20 \%$ methanol, $\mathrm{pH}$ 8.3) using a BioRad Mini Protean II transblot cell and Bio-Ice unit (Towbin et al. 1979). The nitrocellulose was cut into strips and blocked overnight in BLOTTO (Jagus \& Pollard 1988). Strips were then incubated $2 \mathrm{~h}$ in either BLOTTOdiluted sample $(1: 20)$ or standard $(1: 40)$ trout sera. This was followed with a $1 \mathrm{~h}$ incubation in a goat anti-trout antibody conjugated to alkaline phosphatase (Kirkegaard and Perry, Gaithersburg, MD) diluted 1:100 in BLOTTO. In between incubations, strips were washed 3 times in PBS-Tween $20(0.1 \%) ; 1$ additional PBS wash without detergent was done before addition of substrate. For color development, the 5-bromo-4chloro-3-indolyl-phosphate/nitroblue tetrazolium substrate (Kirkegaard and Perry) was added to blots for approximately $30 \mathrm{~min}$. Strips were then rinsed in Type 1 reagent grade water and dried between sheets of Whatman filter paper. Bands were analyzed for molecular weights for relative molecular weights in the case of nonprotein antigens) and quantitation of the antibody response using an imaging densitometer (BioRad model GS-670) and Molecular Analystrm software (BioRad).

Statistical analysis. Due to low mortality in vaccinated groups, survival rates were compared using Fisher's Exact Test; probabilities of less than 1\% were considered significant and reported as $p<0.01$. When appropriate, standard errors were calculated for mean days to death (MDD). Individual ELISA titers are presented for each group $(n=5)$ to avoid masking key elements of the antibody kinetics; titers were calculated by the titration method (Tijssen 1985) and cut-off values were based upon the mean of 10 control samples in duplicate at each dilution plus 4 standard deviations. Molecular mass determinations for Western blot densitometry utilized a cubic regression analysis (Molecular Analyst ${ }^{\mathrm{TM}}$ software, version 2.1/Macintosh, BioRad) of low range prestained protein standards.

Experimental calendar. The schedule for immunizations and challenges, as well as corresponding fish weights, is displayed in Table 1. Primary immuniza- 
tions were completed on Day 0. Sera were collected for the first ELISA on Day 3 and again every $7 \mathrm{~d}$ thereafter through Day 59. Sera for Western blots were collected on Days $19,34,48$, and 55.

\section{RESULTS}

\section{Protection conferred by vaccines before and after boosting}

The in vivo immune response of rainbow trout to the Vibrio anguillarum vaccines was determined using bath challenge $28 \mathrm{~d}$ after completion of primary immunizations and $49 \mathrm{~d}$ after completion of booster immunizations (91 d after primary immunizations). The first challenge (Table 2) utilized a concentration of $4.5 \times 10^{6}$ CFU ml $\mathrm{m}^{-1}$ and demonstrated equally strong protection in all 3 vaccinated groups. RPS (relative percent survival) values ranged from $88.2 \%$ for the orally vaccinated group to $100 \%$ for the injection-vaccinated group. The proportions of survivors in the 3 groups were not significantly different from each other

Table 2. Oncorhynchus mykiss. Mortality and mean days to death (MDD) of rainbow trout challenged by $1 \mathrm{~h}$ immersion exposure to $4.5 \times$ $10^{6}$ waterborne Vibrio anguillarum cells $\mathrm{ml}^{-1} 28 \mathrm{~d}$ after primary vaccination. Fisher's Exact Test was used to measure the probability that each vaccinated group was different from the positive control. Relative percent survival $(\mathrm{RPS})=1-(\%$ vaccinate mortality $/ \%$ positive control mortality) $\times 100 \%$. Standard errors of the MDD given in parentheses

\begin{tabular}{|lcccc|}
\hline Fish group & $\begin{array}{c}\text { Mortality } \\
(\%)\end{array}$ & $\begin{array}{c}\text { Fisher's } \\
\text { Exact Test }\end{array}$ & $\begin{array}{c}\text { RPS } \\
(\%)\end{array}$ & MDD \\
\hline Negative control & 0 & - & - & - \\
Positive control & 42.5 & - & - & $5.1(0.26)$ \\
Oral vaccine & 5.0 & $\mathrm{p}<0.01$ & 88.2 & $4.5(0.50)$ \\
Immersion vaccine & 2.5 & $\mathrm{p}<0.01$ & 94.1 & 13.0 \\
Injection vaccine & 0 & $\mathrm{p}<0.01$ & 100.0 & - \\
\hline
\end{tabular}

Table 3. Oncorhynchus mykiss. Mortality and mean days to death (MDD) of rainbow trout challenged by $1 \mathrm{~h}$ immersion exposure to $8.6 \times$ $10^{7}$ waterborne Vibrio anguillarum cells $\mathrm{ml}^{-1} 91 \mathrm{~d}$ after primary vaccination and $49 \mathrm{~d}$ after booster vaccination. Fisher's Exact Test was used to measure the probability that each vaccinated group was different from the positive control. Relative percent survival (RPS) $=1-(\%$ vaccinate mortality $/ \%$ positive control mortality) $\times 100 \%$. Standard errors of the MDD given in parentheses

\begin{tabular}{|lcccc|}
\hline Fish group & $\begin{array}{c}\text { Mortality } \\
(\%)\end{array}$ & $\begin{array}{c}\text { Fisher's } \\
\text { Exact Test }\end{array}$ & $\begin{array}{c}\text { RPS } \\
(\%)\end{array}$ & MDD \\
\hline Negative control & 0 & - & - & - \\
Positive control & 45.0 & - & - & $5.5(0.41)$ \\
Oral vaccine & 7.5 & $\mathrm{p}<0.01$ & 83.3 & $8.8(2.67)$ \\
Immersion vaccine & 0 & $\mathrm{p}<0.01$ & 100.0 & - \\
Injection vaccine & 0 & $\mathrm{p}<0.01$ & 100.0 & - \\
\hline
\end{tabular}

(Fisher's Exact Test, $\mathrm{p}>0.01$ ). The mortality rate of the positive controls (challenged, not vaccinated) was $42.5 \%$, which corresponds well with the mortality rate of a typical Vibrio anguillarum epizootic (Evelyn \& Ketcheson 1980). The MDDs for both the positive controls and the oral vaccinates were approximately $5 \mathrm{~d}$, whereas the lone immersion-vaccinated mortality did not occur until $13 \mathrm{~d}$ post challenge.

Although the second challenge (Table 3) utilized a higher bacterial concentration $(8.6$ $\times 10^{7} \mathrm{CFU} \mathrm{ml}^{-1}$ ), equally strong protection was observed in all 3 vaccinated groups. No mortalities occurred in the immersion- or injection-vaccinated groups. The RPS of the oral vaccinates was $83.3 \%$. The proportion of oral vaccinates which survived was not significantly different from those of the other 2 vaccinated groups ( $p>0.01)$. The mortality rate of the positive controls was representative of a typical epizootic of this pathogen $(45 \%)$. The MDD of the oral vaccinates (8.8 d) was greater than that of the positive controls $(5.5 \mathrm{~d})$.

\section{Kinetics of the specific humoral response}

Before boosting on Day 42, the oral vaccinates showed almost no serum antibody response as measured by ELISA (Fig. 1). Only 1 fish had detectable antibodies, a titer 
Fig. 1 Oncorhynchus mykiss. Kinetics of the serum antibody response of rainbow trout following primary and booster vaccinations via the oral route of delivery. Booster doses were completed $42 \mathrm{~d}$ post initial vaccination. Bars represent titers of individual fish determined by ELISA, 5 fish being sampled each week

Fig. 2. Oncorhynchus mykiss Kinetics of the serum antibody response of rainbow trout following primary and booster vaccinations via the immersion route of delivery. Booster doses were given 42 d post initial vaccination. Bars represent titers of individual fish determined by ELISA, 5 fish being sampled each week
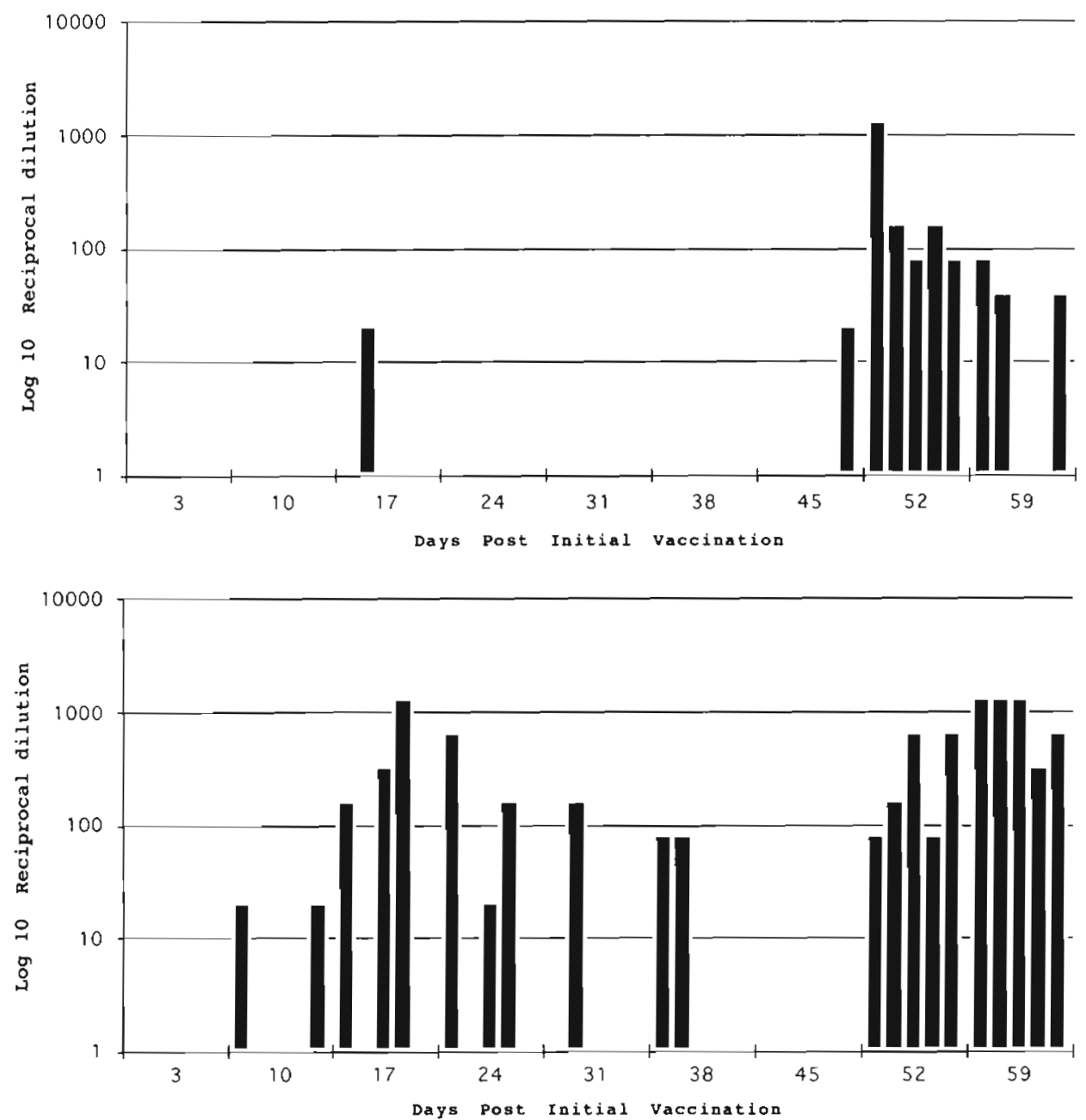

of 20 on Day 17. After boosting, substantial titers were noted with a peak occurring $10 \mathrm{~d}$ after boosting (Day 52) when all 5 fish had detectable levels of antibody (titers ranging from 80 to $1280+$ ).

Before boosting, antibody was detected in $37 \%$ $(11 / 30)$ of the immersion vaccinates (Fig. 2) with titers ranging from 20 to $1280+$. Antibody was first detected $10 \mathrm{~d}$ after primary vaccination. Three days after boosting (Day 45), no specific antibody was detected in any of the immersion vaccinates sampled. However, all fish sampled 10 and $17 \mathrm{~d}$ post booster vaccination had measurable specific antibody levels, with titers from 80 to $1280+$

Before boosting, all injection vaccinates sampled after Day 10 exhibited measurable ELISA titers (Fig. 3). One fish had a titer of 20 on Day 10; by Day 17, all fish had measurable titers. Antibody titers dropped on Day 45, $3 \mathrm{~d}$ after the second set of vaccinations, and 1 of the fish sampled had no measurable antibody. Ten and $17 \mathrm{~d}$ after boosting, all but 1 fish had titers of 1280 or higher.

\section{Antigenic analysis of vaccinated groups}

SDS-PAGE and Western blot assays, coupled with scanning densitometry analysis, revealed the nature and pattern of the antibody response among treatment groups. Information to be derived from such assays includes identification of the antigens (or molecular weight groups of antigens) to which the fish were responding and the relative strength of the response to those antigens or groups of antigens. Pooled sera from 90 unvaccinated and 90 injection-vaccinated fish were used as negative and positive standards, respectively (Fig. 4). The positive standard serum reacted strongly with a group of antigens (probably at least 5) in the 30 to $45 \mathrm{kDa}$ range.

The 4 rainbow trout treatment groups (control, oral vaccinates, immersion vaccinates, injection vaccinates) were sampled on experimental Days 19, 34, 48, and 55 for Western blot analysis. Day 19 blots incubated with vaccinated sera did not show any response beyond that of the control groups. Day 34 blots exhibited a moder- 


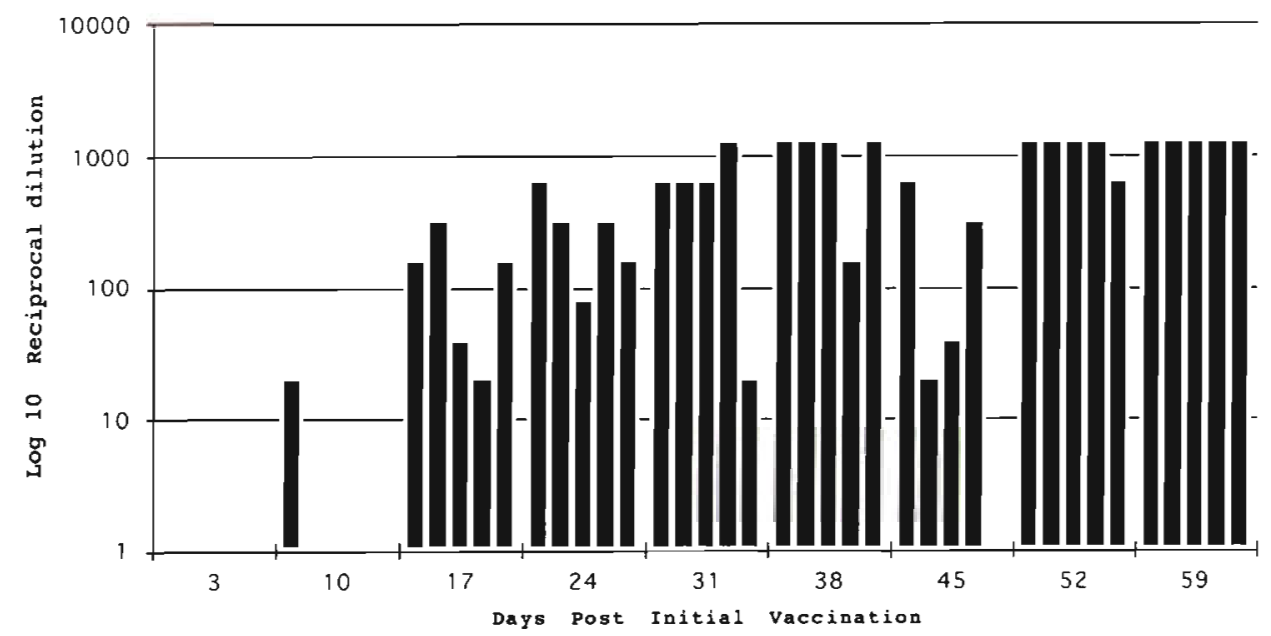

Fig. 3. Oncorhynchus mykiss Kinetics of the serum antibody response of rainbow trout following primary and booster vaccinations via the injection route of delivery. Booster doses were given $42 \mathrm{~d}$ post initial vaccination. Bars represent titers of individual fish determined by ELISA, 5 fish being sampled each week

ate response with injection-vaccinated sera producing peaks between 30 and $40 \mathrm{kDa}$ and with immersionvaccinated sera producing peaks between 30 and $35 \mathrm{kDa}$. Strong responses were observed on Day 55 with both injection- and immersion-vaccinated sera (between 28 and $44 \mathrm{kDa}$ ). Clearest differences among the treatment groups, however, were detectable on Day 48 and only these scanning densitometer tracings are shown (Figs. 4 to 6 ).

The densitometric tracing of the control serum (not shown) showed almost no response in the 20 to $140 \mathrm{kDa}$ target area, with no bands distinguishable from those of the negative standard tracing. The serum tracing for oral vaccinates (not shown) also did not exhibit any clear bands that were distinguishable from those of the

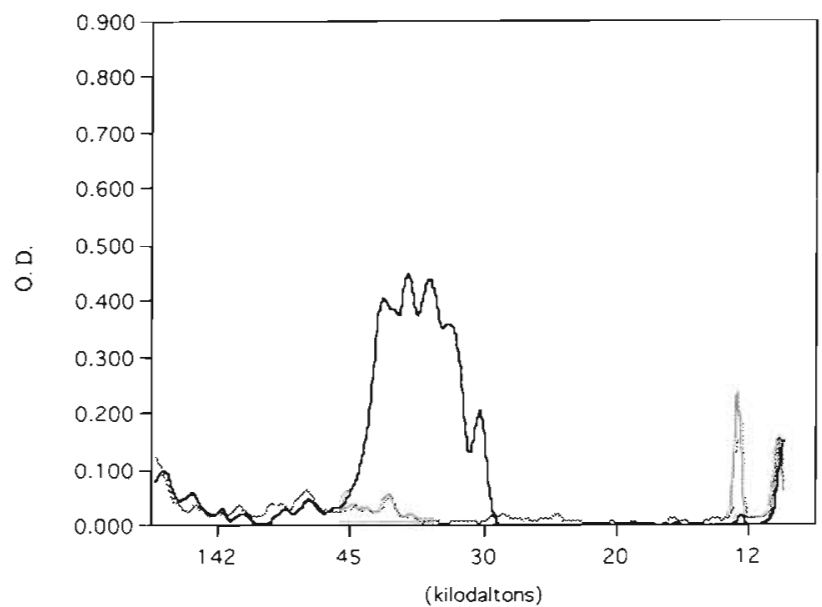

Fig. 4. Scanning densitometer analysis (reflectance mode) of a Western blot of positive standard rainbow trout serum (bold line) reacting to a sonicated Vibrio anguillarum whole cell lysate. Positive standard was a collection of pooled sera from 90 rainbow trout vaccinated and boosted by injection $(0.2 \mathrm{cc}$ intraperitoneally) with a formalin-killed whole cell $V$. anguillarum bacterin with broth. Negative standard tracing is shown for comparison. O.D.. optical density negative standard or control tracing. Several distinct bands appeared in the 30 to $40 \mathrm{kDa}$ area on the serum tracing of immersion-vaccinated fish (Fig. 5), as well as some response to a couple of high molecular weight bands. Finally, the densitometer tracing of injected fish (Fig. 6) showed a strong response to several bands in a narrow range between 28 and $44 \mathrm{kDa}$.

\section{DISCUSSION}

The use of immunization to successfully protect fish against vibriosis was first reported in 1964 (Hayashi et al. 1964). In that study, the route of administration utilized was intraperitoneal injection. Since that time,

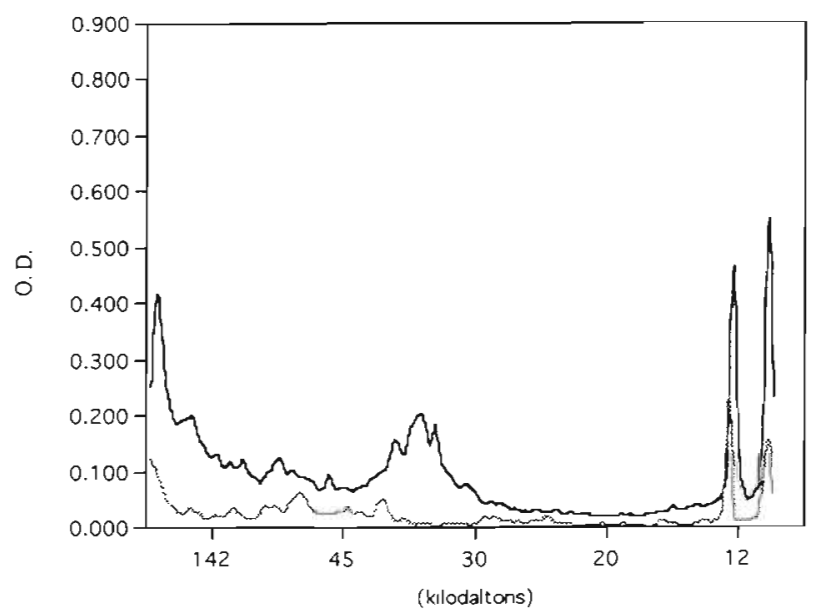

Fig. 5. Scanning densitometer analysis (reflectance mode) of a Western blot of immersion-vaccinated rainbow trout serum (bold line) reacting to a sonicated Vibrio anguillarum whole cell lysate. Serum was collected and pooled from 2 rainbow trout $48 \mathrm{~d}$ after immersion primary vaccination and 6 d after immersion booster vaccination. Negative standard tracing is shown for comparison. O.D.: optical density 


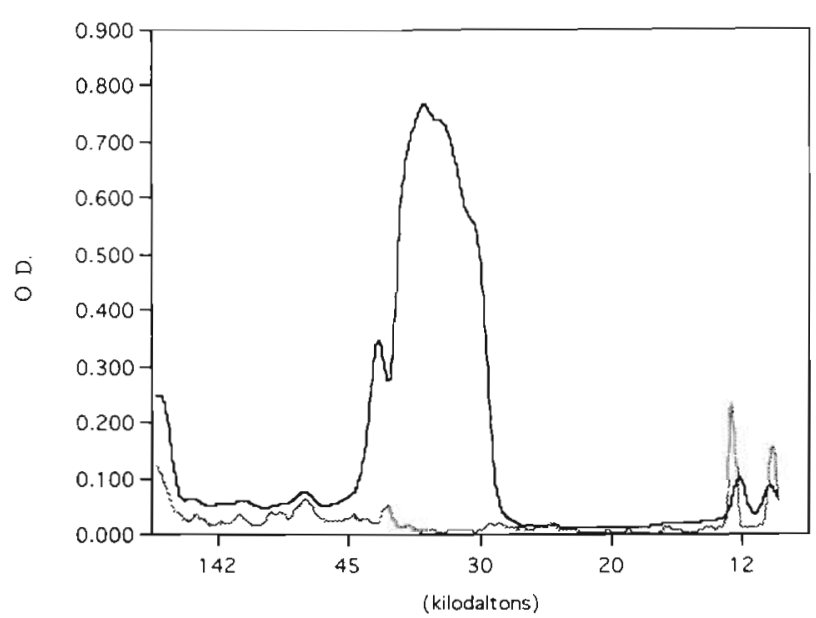

Fig. 6. Scanning densitometer analysis (reflectance mode) of a Western blot of injection-vaccinated rainbow trout serum (bold line) reacting to a sonicated Vibrio anguillarum whole cell lysate. Serum was collected and pooled from 2 rainbow trout $48 \mathrm{~d}$ after injection primary vaccination and $6 \mathrm{~d}$ after injection booster vaccination. Negative standard tracing is shown for comparison. O.D.: optical density

injection vaccination has been shown to provide strong protection, not only against vibriosis, but also against a number of other extracellular bacteria that are pathogenic to fish, including Yersinia ruckeri (Ellis 1988b) and Aeromonas salmonicida (Hastings 1988). Immersion vaccination was first described by Amend and others for protection against enteric redmouth disease (ERM) and vibriosis (Amend \& Fender 1976, Antipa \& Amend 1977, Croy \& Amend 1977, Busch 1978, Antipa et al. 1980, Amend et al. 1983). Immersion delivery is still used extensively today to combat these diseases. Most investigators consider immersion immunization to provide a level of protection that is less than that conferred by injection but stronger and more consistent than that provided by oral immunization. While oral immunization has not been highly regarded, one should remember that the first report of protection of fish against extracellular bacteria (Duff 1942) involved oral delivery of chloroform-killed $A$. salmonicida cells to cutthroat trout. The first successful test of an ERM vaccine also utilized oral immunization (Ross \& Klontz 1965). Despite these early successes and the substantial practical advantages afforded by oral administration, oral vaccines for fish are still largely experimental because of poor or inconsistent protection (Quentel \& Vigneulle 1997).

In contrast to most previous reports on fish vaccine efficacy (Lamers 1985, Ellis 1988a, Nakanishi \& Ototake 1997, Quentel \& Vigneulle 1997), the data presented here indicate that the degree of protection conferred against waterborne challenges of Vibrio anguillarum 775 was equal for injection-, immersion-, and orally vaccinated treatment groups with and with- out boosting (Tables $2 \&$ 3). Lillehaug (1989) achieved similar levels of protection with these routes of vaccine delivery following bath and cohabitation challenges with $V$. anguillarum; however, the oral vaccines were delivered by intubation rather than feeding and $2 \mathrm{~V}$. anguillarum serotypes were used in each challenge method. Additionally, the challenge conditions were different from the present study; in particular, fish were challenged $40 \mathrm{~d}$ after vaccination (rather than $28 \mathrm{~d}$ ) and, on the day of the challenge, fish were moved from one facility with $12^{\circ} \mathrm{C}$ freshwater to another facility with $15^{\circ} \mathrm{C}$ saltwater $(25 \%)$. No information was provided on fish density or challenge culture concentration. The approximate antigenic doses administered orally per fish were $30 \mathrm{mg}$ dry weight of vaccine in the Lillehaug (1989) study versus $13.5 \mathrm{mg}$ wet pack cells in our study. Johnson \& Amend (1983) used oral and anal intubation to investigate the efficacy of a commercial $V$. anguillarum bacterin administered to $5 \mathrm{~g}$ sockeye salmon. In general, fish vaccinated by anal intubation were better protected than fish vaccinated by oral intubation. In challenges conducted $28 \mathrm{~d}$ after primary vaccination, the 2 oral intubation treatment groups in the Johnson \& Amend (1983) study were less well protected than the oral vaccinates in our study ( 35 and $69 \%$ versus $5 \%$ mortality). In both of these studies, unvaccinated controls experienced similar or lower mortalities during later (Days 59 or 91) versus earlier (Day 28) challenges despite higher challenge levels at the later dates (Tables $2 \& 3$ ). These results may reflect stronger pathogen resistance in larger fish. Immunological studies of higher vertebrates have established that circulating antibody is the principal protective immune response against extracellular bacteria (Abbas et al. 1991). For example, human patients with pure B-cell defects are not able to control infections caused by extracellular bacteria (Janeway \& Travers 1994). In the fisheries literature, there appears to be confusion regarding the importance of humoral factors. This confusion reflects the inability of investigators to consistently correlate protection with levels of circulating specific antibody.

With Vibrio anguillarum, the protective role of antibody has been demonstrated following injection vaccination (Thuvander et al. 1987) and passive immunization (Harrell et al. 1975). However, the correlation has not always been clear after immersion vaccination, and most studies on oral vaccination against vibriosis have shown no correlation (Smith 1988, Quentel \& Vigneulle 1997). Thuvander et al. (1987) concluded that the importance of low levels of antibodies is unclear, but that the presence of specific antibodies in a proportion of the fish after vaccination seems to indicate that the whole population is protected. This appears to be the case in the current study, where low ELISA 
titers in immersion vaccinates before boosting (Fig. 2) were coupled with a high level of protection in the first challenge (Table 2). Bøgwald et al. (1994) found moderate to high levels of specific circulating antibody after intraperitoneal immunization with formalinkilled, washed whole cells of $V$. salmonicida, $V$. anguillarum (serotype 01), V. anguillarum (serotype 02), and Aeromonas salmonicida. However, in the same study, no specific antibodies could be demonstrated after oral administration of the same vaccines. In our study, essentially the same results occurred. Little antibody activity was evident in oral vaccinates before boosting but protection was high. Consistent specific serum antibody titers appeared only after boosting (Fig. 1).

The kinetics of the antibody responses in the orally, immersion-, and injection-vaccinated groups before boosting (Figs. 1 to 3 ) were similar to the results of some previous studies (Smith 1988, Nakanishi \& Ototake 1997, Quentel \& Vigneulle 1997). Injection titers were high and consistent starting on Day 17; immersion titers were sporadic with $63 \%$ of the fish having no detectable levels of antibody; oral titers were almost nonexistent. The dramatic differences between this work and previous work centered on the antibody titers of orally and immersion-vaccinated fish after boosting. Surprisingly strong and consistent antibody titers were measured in all immersion-vaccinated fish sampled 10 and $17 \mathrm{~d}$ after boosting (Fig. 2). Eight out of 10 orally vaccinated fish showed moderate to strong titers at the same sampling points (Fig. 1). The titers of the oral vaccinates appear to have peaked about $10 \mathrm{~d}$ after boosting while the titers of immersion vaccinates peaked $17 \mathrm{~d}$ after boosting or later, as did those of the injection vaccinates. The experimental design did not permit analysis of antibody titers beyond Day 59 .

The presence of memory lymphocytes is normally determined by monitoring the secondary response (Lamers 1985). In the present study, an anamnestic response was clearly demonstrated in all 3 vaccinated groups (Figs. 1 to 3) as indicated by the speed, strength, and consistency of the secondary response when compared to the primary response. Before 1985 , results of investigations into the piscine anamnestic response were contradictory (Dunier 1985). Since that time, the existence of memory in fish has become generally accepted with the acknowledgment that it can be affected by many factors (fish age, antigenic dose, route of administration, adjuvants, temperature, etc.) and that it differs from immunological memory in mammals. Arkoosh \& Kaattari (1991) postulated that memory responses in rainbow trout may be due to a simple expansion of the antigen specific precursor pool without many of the qualitative changes in antibody or B-cell function that are associated with memory in mammals. To our knowledge, Figs. 1 \& 2 are the first demonstration of humoral anamnestic responses in salmonids following oral and immersion vaccinations in which primary and booster immunization protocols were identical. These results also suggest that circulating antibody responses may have been elicited in most or all of the fish after primary oral and immersion immunizations even though the level of antibodies was generally too low to be detected by the ELISA protocol. This failure to measure antibody may explain much of the confusion among previous investigators, particularly with respect to oral immunization. The results presented here do not rule out the possibility that localized or mucosal antibody responses may also contribute to protection, nor can one assume that specific cellular immunity is not involved as well.

The pattern of antibody responses seen in Western blots did not differ significantly among the positive standards, immersion vaccinates, and injection vaccinates (Figs. 4 to 6). However, the magnitude of the responses among these groups did differ. The antigens to which the fish in these treatment groups responded appear to be mainly antigenic outer membrane proteins identified in previous studies (Chart \& Trust 1984, Norqvist et al. 1989). This observation, together with the fact that no clear responses were observed in the Day 19 blots, may indicate that our Western blot protocol primarily detected antibody responses to protein antigens, while the ELISA may have detected specific antibody to both lipopolysaccharide (LPS) and protein antigens. This could also explain why the oral and immersion vaccinates had very similar ELISA titers on Day 52 , but only the immersion vaccinates had a significant Western blot response on Day 48 (Figs. 1.2 \& 5). Protein antigens in the oral vaccine may have been substantially more degraded in the stomach compared to the LPS antigens. Other investigators have found a similar discrepancy between high ELISA titers and weak immunoblot responses with both human (Wethered et al. 1988) and salmon antisera (Wood \& Kaattari 1996). The observed difference was tentatively attributed to recognition of carbohydrate antigens in ELISA assays that were not adequately detected by immunoblots. Bøgwald et al. (1991) did show some reaction of salmon antisera to Vibrio anguillarum serotype I LPS antigen in a Western blot. However, almost no bands appeared within the range of the molecular weight standards in the $V$. anguillarum serotype II and $V$. salmonicida LPS preparations, while numerous bands were present in the outer membrane preparations. Alternatively, it is possible that total specific antibody levels may have been insufficient to detect many of the key antigens by the Western blot protocol developed for this study. Nevertheless, since LPS typically does not induce memory B-cells in higher vertebrates (Abbas et al. 1991), fish 
vaccine development should probably focus on protein antigens in order to achieve suitable duration of protection

A by-product of this project was further refinement of the rainbow trout -Vibrio anguillarum model system. Gould et al. (1978) concluded that $V$. anguillarum serotype I was an excellent experimental model for testing methods of fish immunization. Their conclusion was based on the antigenicity of bacterins prepared from this organism and the existence of reproducible laboratory challenges that simulate natural exposure. Nelson et al. (1985) agreed and mentioned the additional advantage that vibriosis can be controlled by oral, immersion, and injection routes of vaccine delivery. When this pathogen is combined with rainbow trout, which has been referred to as the aquatic 'white mouse', an extremely versatile model system is created for both applied and basic immunological research. Progress in fish immunology has been hampered to date by the wide variety of pathogens and hosts that have been used.

In summary, injection, immersion, and oral vaccination conferred equal protection to controlled laboratory challenges with Vibrio anguillarum. Protection correlated positively with serum antibody levels after, but not prior to, boosting. Correlation before boosting may be possible if extremely sensitive detection methods are developed. The route of vaccine delivery primarily affected the magnitude and kinetics of the antibody response and did not appear to play a significant role in altering the pattern of the antibody response (as shown by Western blotting). An anamnestic response was clearly demonstrated following oral, immersion, and injection vaccination, using identical protocols for primary and booster immunizations. Finally, a rainbow trout-Vibrio anguillarum 775 model, incorporating 3 routes of vaccine delivery, can be a valuable tool both for research on fish vaccine development and for increasing our understanding of underlying immune mechanisms.

Additional research is needed to confirm and expand upon the results presented here. In particular, work should be done to clarify the roles played by serum antibody, localized antibody, and the specific cellular response. The effects of route of vaccine administration on the response to specific antigens also deserves more attention.

Acknowledgements. We thank S. S. Ristow (Washington State University) for providing the Warr 1-14 hybridoma cells and J. D. Hendricks (Oregon State University) for providing the Oregon Test Diet. We are also grateful to J. L. Fryer, G. E. Kenny, and D. B. Powell for their critiques of the manuscript. M. P. Peña provided critical assistance in monitoring and maintaining wet laboratory water quality parameters. This research was funded by Alpharma, Aquatic Animal Health Division.

\section{LITERATURE CITED}

Abbas AK, Lichtman AH, Pober IS (1991) Cellular and molecular immunology. WB Saunders Company, Philadelphia, PA

Amend DF, Fender DC (1976) Uptake of bovine serum albumin by ralnbow trout from hyperosmotic solutions: a model for vaccinating fish. Science 192:793-794

Amend DF, Johnson KA, Croy TR, McCarthy DH (1983) Some factors affecting the potency of Yersinia ruckeri bacterins J Fish Dis 6:337-344

Antipa R, Amend DF (1977) Immunization of Pacific salmon: comparison of intraperitoneal injection and hyperosmotic infiltration of Vibrio anguillarum and Aeromonas salmonicida bacterins. J Fish Res Bd Can 34:203-208

Antipa R, Gould R, Amend DF (1980) Vibrio anguillarum vaccination of sockeye salmon, Oncorhynchus nerka (Walbaum), by direct and hyperosmotic immersion. J Fish Dis 3:161-165

Arkoosh MR, Kaattari SL (1991) Development of immunological memory in rainbow trout (Oncorhynchus mykiss). 1 An immunological and cellular analysis of the $B$ cell response. Dev Comp Immunol 15: 279-293

Bøgwald J, Stensvåg K, Hoffman J, Jørgensen TØ (1991) Antibody specificities in Atlantic salmon, Salmo salar L., against the fish pathogens Vibrio salmonicida and Vibrio anguillarum. J Fish Dis 14:79-87

Bøgwald J, Stensvåg K, Stuge TB, Jørgensen Tø (1994) Tissue localisation and immune responses in Atlantic salmon, Salmo salar L., after oral administration of Aeromonas salmonicida, Vibrio anguillarum, and Vibrio salmonicida antigens. Fish Shellfish Immunol 4:353-368

Busch RA (1978) Enteric red mouth disease (Hagerman strain). Mar Fish Rev 40:42-51

Chart H, Trust TJ (1984) Characterization of the surface antigens of the marine fish pathogens, Vibrio anguillarum and Vibrio ordalii. Can J Microbiol 30:703-710

Croy TR, Amend DF (1977) Immunization of sockeye salmon (Oncorhynchus nerka) against vibriosis using the hyperosmotic infiltration technique. Aquaculture 12:317-325

DeLuca D, Wilson M, Warr GW (1983) Lymphocyte heterogeneity in the trout Salmo gairdneri defined with monoclonal antibodies to IgM. Eur J Immunol 13:546-551

Duff DCB (1942) The oral immunization of trout against BaCterium salmonicida. J Immunol 44:87-94

Dunier $M$ (1985) Absence of anamnestic antibody response to DNP- haemocyanin and DNP-ficoll in rainbow trout. In: Manning MJ, Tatner MF (eds) Fish immunology. Academic Press, London, p 171-184

Ellis AE (1988a) General principles of fish vaccination. In Ellis AE (ed) Fish vaccination. Academic Press, London, p $1-19$

Ellis AE (1988b) Vaccination against enteric redmouth (ERM). In: Ellis AE (ed) Fish vaccination. Academic Press, London, $\mathrm{p}$ 85-92

Engvall E, Perlmann P (1972) Enzyme-linked immunosorbent assay, ELISA: quantitation of specific antibodies by enzyme-labeled anti-immunoglobulin in antigen-coated tubes. J Immunol 109:129-135

Evelyn TPT, Ketcheson JE (1980) Laboratory and field observations on antivibriosis vaccines. In: Ahne W (ed) Fish diseases. Third COPRAQ-Session. Springer-Verlag, Berlin, p 45-52

Gould RW, O'Leary PJ, Garrison RL, Rohovec JS, Fryer JL (1978) Spray vaccination: a method for the immunization of fish. Fish Pathol 13:63-68

Gudkovs N (1988) Fish immunology. In: Fish diseases. Pro- 
ceedings 106. Post Graduate Committee in Veterinary Science, University of Sydney, p 531-544

Hammond JBW, Kruger NJ (1988) The Bradford method for protein quantitation. In: Walker JM (ed) Methods in molecular biology, Vol 3. New protein techniques. Humana Press, Clifton, NJ, p 25-32

Harrell LW, Etlinger HM, Hodgins HO (1975) Humoral factors important in resistance of salmonid fish to bacterial diseases. I. Serum antibody protection of rainbow trout (Salmo gairdneri) against vibriosis. Aquaculture 6: $211-220$

Harrell LW, Novotny AJ, Schiewe MH, Hodgins HO (1976) Isolation and description of two vibrios pathogenic to Pacific salmon in Puget Sound, Washington. US Nat Mar Fish Ser Fish Bull 74:447-449

Hastings TS (1988) Furunculosis vaccines. In: Ellis AE (ed) Fish vaccination. Academic Press, London, p 93-111

Hayashi K, Kobayashi S, Jamata T, Ozaki H (1964) Studies on the vibrio disease of rainbow trout (Salmo gairdneri irideus). II. Prophylactic vaccination against the vibriodisease. J Fac Fish Pref Univ Mie-Tsu 6:181-191

Horne MT, Tatner MF, Ward PD (1984) Vaccination of fish: a practical view. Vet Rec June:537-539

Jagus R, Pollard JW (1988) Use of dried milk for immunoblotting. In: Walker JM (ed) Methods in molecular biology, Vol 3. Humana Press, Clifton, NJ, p 403-408

Janeway CA Jr, Travers P (1994) Immunobiology: the immune system in health and disease. Current Biology, London

Johnson KA, Amend DF (1983) Efficacy of Vibrio anguillarum and Yersinia ruckeri bacterins applied by oral and anal intubation of salmonids. J Fish Dis 6:473-476

Laemmli UK (1970) Cleavage of structural proteins during the assembly of the head of bacteriophage T4. Nature 227 : $680-685$

Lamers CHJ (1985) The reaction of the immune system of fish to vaccination. PhD thesis, Agricultural University, Wageningen

Lillehaug A (1989) Oral immunization of rainbow trout, Salmo gairdneri Richardson, against vibriosis with vaccines protected against digestive degradation. J Fish Dis 12: $579-584$

Nakanishi T, Ototake M (1997) Antigen uptake and immune responses after immersion vaccination. In: Gudding $R_{\text {, }}$ Lillehaug A, Midtlyng PJ, Brown F (eds) Fish vaccinology. Dev Biol Stand 90:59-68

Editorial responsibility: David Bruno,

Aberdeen, Scotland, UK
Nelson JS, Rohovec JS, Fryer JL (1985) Tissue location of vibrio bacterin delivered by intraperitoneal injection, immersion and oral routes to Salmo gairdneri. Fish Pathol 19: $263-269$

Norquist A, Hagström $\AA$, Wolf-Watz H (1989) Protection of rainbow trout against vibriosis and furunculosis by the use of attenuated strains of Vibrio anguillarum. Appl Environ Microbiol 55:1400-1405

Palm RC Jr (1996) Specific humoral response of rainbow trout Oncorhynchus mykiss to injection, immersion, and oral immunization against Vibrio anguillarum. PhD thesis, University of Washington, Seattle

Quentel C, Vigneulle M (1997) Antigen uptake and immune responses after oral vaccination. In: Gudding $\mathrm{R}$, Lillehaug A, Midtlyng PJ, Brown $F$ (eds) Fish vaccinology. Dev Biol Stand 90:69-78

Ross AJ, Klontz GW (1965) Oral immunization of rainbow trout against the etiological agent of redmouth disease. J Fish Res Bd Can 22:713-719

Sinnhuber RO, Hendricks JD, Wales JH, Putman GB (1977) Neoplasms in rainbow trout, a sensitive environmental model for environmental carcinogenesis. Ann NY Acad Sci 298:389-408

Smith PD (1988) Vaccination against vibriosis. In: Ellis AE (ed) Fish vaccination. Academic Press, London, p 67-84

Thuvander A, Hongslo T, Jannson E, Sundquist B (1987) Duration of protective immunity and antibody titres measured by ELISA after vaccination of rainbow trout, Salmo gairdneri Richardson, against vibriosis. J Fish Dis 10: $479-486$

Tijssen P (1985) Laboratory techniques in biochemistry and molecular biology, Vol 15. Elsevier, Amsterdam

Towbin H, Staehelin T, Gordon J (1979) Electrophoretic transfer of proteins from polyacrylamide gels to nitrocellulose: procedures and some applications. Proc Natl Acad Sci USA 76:4350-4354

Wethered DB, Markey MA, Hay RJ, Mahgoub ES, Guman SA (1988) Humoral immune responses to mycetoma organisms: characterization of specific antibodies by use of enzyme-linked immunoabsorbant-assay and immunoblotting. Trans R Soc Trop Med Hyg 82:918-923

Wood PA, Kaattari SL (1996) Enhanced immunogenicity of Renibacterium salmoninarum in chinook salmon after removal of the bacterial cell surface-associated $57 \mathrm{kDa}$ protein. Dis Aquat Org 25:71-79

Submitted: November 3, 1997; Accepted: April 3, 1998

Proofs received from author(s): July 24, 1998 